\title{
How Do Exporters Respond to Antidumping Investigations?
}

\author{
Yi Lu, ${ }^{\mathrm{a}}$ Zhigang Tao, ${ }^{\mathrm{b}}$ and Yan Zhang ${ }^{\mathrm{b}}$ \\ ${ }^{a}$ National University of Singapore \\ b University of Hong Kong
}

Revised: August 2013

\begin{abstract}
Using monthly transaction data covering all Chinese exporters over the 20002006 period, we investigate how Chinese exporters respond to U.S. antidumping investigations. We find that antidumping investigations cause a substantial decrease in the total export volume at the HS-6 digit product level, and that this tradedampening effect is due to a significant decrease in the number of exporters, yet a modest decrease in the export volume per surviving exporter. We also find that the bulk of the decrease in the number of exporters is exerted by less productive exporters, by direct exporters as opposed to trade intermediaries, and by singleproduct direct exporters as opposed to their multi-product counterparts. Combined with the existing studies on the effects that antidumping investigations have on protected firms, our study helps piece together a complete picture of the effects of antidumping investigations.
\end{abstract}

Keywords: Antidumping investigations; Difference-in-differences estimation; Extensive and intensive margins; Trade intermediaries; Single- versus multi-product exporters

JEL Codes: F13; D22; F14; L25 


\section{Introduction}

Despite the increasing trend in international trade due to rounds of tariff reductions and advancements in telecommunications and logistics, we have witnessed persistent and even increasing use of contingent trade protection policies (e.g., Prusa, 2001; Zanardi, 2006; Bown, 2011). In particular, governments around the world have resorted to antidumping measures, which are permissible under the World Trade Organization (WTO) rules and regulations, to protect their firms and industries, especially in times of economic difficulty. The widespread use of antidumping measures has spurred economists to study their effects on firm behavior, which has significant implications for national competitiveness and longrun economic growth. ${ }^{1}$

While significant insights have been gained from the literature regarding the effects of antidumping measures on protected domestic firms and industries, ${ }^{2}$ much less is known about the corresponding impacts on affected foreign exporters. ${ }^{3}$ Understanding how affected foreign exporters respond to antidumping measures is, however, an essential component in piecing together a picture of market competition between domestic firms and foreign exporters in both the short run (i.e., right after antidumping measures) and the long run (i.e., after the expiration of antidumping measures) and its implications for industry dynamics and the national economy. Moreover, understanding whether affected exporters should continue their exporting behavior in response to the negative shocks generated by antidumping investigations complements the existing firm heterogeneity literature, which focuses primarily on the decision to enter the export market.

This paper provides the first empirical analysis of how affected foreign exporters respond to antidumping investigations. Specifically, we use antidumping cases filed by the U.S. against Chinese exporters over the 2000-2006 period.

We choose this research setting for two reasons. China, the world's largest exporter, has become the world's largest target of antidumping measures. Meanwhile, the U.S. is the world's second largest initiator of antidumping cases against China, due to its rising trade deficit with China and the apparently related loss of manufacturing jobs in the U.S. (see, for example, Autor, Dorn, and Hanson, forthcoming; Pierce and Schott, 2012).

To conduct the empirical investigation, we draw on data from two sources: China Customs data (2000-2006) and the World Bank global antidumping database. From the first data set, we obtain information on monthly export transactions at the Chinese HS-8 digit product level by all Chinese exporters to the U.S., including export volume, export value, and exporter identity. From the second data set, we compile all the antidumping

\footnotetext{
${ }^{1}$ For surveys of studies on antidumping, see Blonigen and Prusa (2003) and Falvey and Nelson (2006).

${ }^{2}$ For recent studies, see, for example, Gallaway, Blonigen and Flynn (1999); Konings and Vandenbussche (2008); and Pierce (2011).

${ }^{3} \mathrm{~A}$ few papers look at how antidumping duties affect foreign exporters' pricing behavior (Blonigen and Park, 2004), export-destination diversification (Bown and Crowley, 2006, 2007) and FDI strategies for serving foreign markets (Blonigen, 2002).
} 
investigations carried out by the U.S. against Chinese exporters at the U.S. HS-10 digit product level over the 2000-2006 period, including information such as initiation date, preliminary determination dates, and final determination dates. The two data sets are then combined at the HS-6 digit product level, which is common to China and the U.S.

Our identification strategy relies on the comparison of outcome variables (such as export volume, number of exporters, export price, and trade deflection) for exporters in the affected product category (the treatment group) with the same variables for those in the unaffected product category (the control group) before and after the various important stages in the antidumping investigation process, i.e., the difference-in-differences (or DID) method. Specifically, we use two alternative control groups. First, for an HS-6 digit product subject to antidumping investigations, we use all other unaffected HS-6 digit products within the same HS-4 digit category as the control group. Second, we follow Blonigen and Park (2004) in constructing a matched control group based on the likelihood of products being subject to antidumping investigations.

We find that antidumping investigations cause a substantial decrease in the total export volume at the HS-6 digit product level, and that this trade-dampening effect is due to a significant decrease in the number of exporters (extensive margin effect), yet a modest decrease in the export volume per surviving exporter (intensive margin effect). Meanwhile, we find that there is little change in freight on board (F.O.B.) export price and no change in the exports of the concerned products to markets other than the U.S. (trade deflection effect). Probing the underlying causes for the substantial extensive margin effect of the antidumping investigations, we find that less productive exporters are more likely to exit the U.S. market; direct exporters are more likely than trade intermediaries to exit the U.S. market; and single-product direct exporters are more likely than multiproduct direct exporters to exit the U.S. market.

These results are found to be robust in a series of checks on various potential data and estimation issues, such as validity checks on the DID estimation, quarterly data (instead of monthly data), exclusion of outlying observations, inclusion of unsuccessful and withdrawn cases, exclusion of antidumping cases under investigation by other countries, exclusion of processing traders and foreign firms, a check on the aggregation bias, controlling for other trade shocks such as U.S. safeguard investigations and China's WTO accession, differential effects across products with different import demand elasticities, and an alternative definition of single-product direct exporters (see Section 5.6 for details).

Our results suggest that U.S. antidumping investigations drive weaker Chinese exporters out of the U.S. market, leaving behind the more productive ones, often with multimarket and multi-product coverage. Meanwhile, previous studies (e.g., Pierce, 2011) on the effects of U.S. antidumping measures on its domestic, protected firms have shown that protection through the temporary imposition of antidumping duties is more tilted 
toward the weaker domestic producers, thereby slowing down the resource reallocation towards the more productive producers. Taken together, U.S. antidumping investigations definitely bring temporary benefits to domestic producers who expand their market share, as Chinese imports substantially fall and numerous Chinese exporters exit the market. In the long run (especially when the antidumping duties are lifted), however, antidumping investigations may spell more troubles for U.S. domestic producers in their competition with the Chinese exporters, as the former becomes less productive on average while the latter becomes more productive.

The remainder of this paper is organized as follows. Section 2 describes the institutional background of antidumping investigations in the U.S. The estimation strategy is discussed in Section 3 and data are reported in Section 4. Section 5 presents empirical findings and some discussions of these results. The paper concludes with Section 6 .

\section{Institutional Background of Antidumping Investi- gations in the U.S.}

In this section, we briefly describe the institutional context of antidumping investigations in the U.S. and its relevance to our identification strategy (Staiger and Wolak, 1994).

In the U.S., there are two government bodies involved in antidumping investigations: the Department of Commerce (DoC) and the International Trade Commission (ITC). The DoC determines whether an imported product under investigation is sold in the U.S. at less than its "fair value", while the ITC determines whether the imported product has materially injured the relevant U.S. domestic industries. Each of these two bodies makes two determinations, i.e., the preliminary and final determinations.

Once an antidumping petition against an imported product is filed and then considered, the ITC first makes a preliminary determination within 45 days. If the determination is negative, the investigation is terminated. Otherwise (i.e., where the preliminary ITC determination is affirmative), the DoC conducts its investigation and makes a preliminary determination in the next 115 days. Regardless of the DoC's preliminary determination (affirmative or negative), the investigation process continues. However, if the DoC's preliminary determination is affirmative, importers of the affected imported product must post a cash deposit or bond to cover the dumping duties the DoC estimates to be payable.

After the DoC's preliminary determination but before the ITC's final determination, the antidumping investigation can be terminated due to withdrawal by the petitioner(s), or can be suspended due to agreements reached between affected foreign exporters and the DoC. If an antidumping investigation is neither terminated nor suspended, the investigation moves on to the next stage, in which the DoC makes a final determination 
within 75 days of its preliminary decision. If the DoC's final determination is negative, the investigation is terminated. Otherwise, the ITC has 45 (or 75) days to conduct a second round of investigation and make a final determination, depending on whether the DoC's preliminary determination was affirmative (or negative). Once both the DoC and the ITC reach affirmative final determinations, the DoC must issue an antidumping order to levy antidumping duties within 7 days.

In summary, there are five important points in time during an antidumping investigation: initiation, the preliminary ITC determination, the preliminary DoC determination, the final DoC determination, and the final ITC determination.

\section{Estimation Strategy}

In contrast to the yearly data used in most of the literature, our monthly export transaction data allow us to investigate whether exporters respond differently to different stages of the antidumping investigation process. As noted in the Section 2, there are five stages in an antidumping investigation: initiation of the case, the preliminary ITC determination, the preliminary DoC determination, the final DoC determination, and the final ITC determination. Given that the DoC makes affirmative determinations in most antidumping cases, we focus on the three remaining dates in the antidumping investigation, i.e., the initiation date, the date of the preliminary ITC determination, and the date of the final ITC determination. The affirmative final ITC determination leads to the imposition of dumping duties, which consequently increase the costs of the export products concerned for the U.S. importers. The affirmative preliminary ITC determination, combined with (almost certainly an) affirmative preliminary DoC determination, requires U.S. importers to pay a deposit as a bond for the expected dumping duties. Even the initiation of an antidumping investigation might have an effect on U.S. importers, as it brings uncertainty to their businesses. We therefore expect exporters to have progressively negative responses to the following three stages of an antidumping investigation: initiation, preliminary ITC determination, and final ITC determination. Moreover, different exporters (i.e., with different productivity levels; trade intermediaries versus direct exporters; single-product direct exporters versus multi-product direct exporters) may respond differently during different stages of the antidumping investigation process.

To identify the possible effects of antidumping investigations, we employ the DID estimation strategy at both the product (defined as the HS-6 digit level) and firm-product levels. Specifically, we exploit two sources of variations: time variation (before and after a critical date in the antidumping investigation process) and cross-sectional variation (affected products/firms or the treatment group, and unaffected products/firms or the control group). The identification relies on a comparison of outcome variables for the treatment group with those for the control group both before and after the relevant 
stages of the antidumping investigation process.

We construct two alternative control groups. The first encompasses all unaffected products/firms within the HS-4 digit product category to which the affected products/firms belong (referred to as Control Group 1). The second control group is a matched group (referred to as Control Group 2) constructed using the method employed by Blonigen and Park (2004). Specifically, we first estimate the probability of a product being subject to antidumping investigations (see Table A.1 of the Appendix for the Logit regression results). The variables used to predict the probability of being investigated for dumping include the import value of the product, the real GDP growth rate in the U.S., an exchange rate index, a dummy variable indicating whether the product was previously subject to antidumping investigations, and an HS 4-digit product dummy, similar to those used by Blonigen and Park (2004). The matched control group comprises unaffected products with predicted probabilities equal to at least the 75 th percentile of the predicted probability of the treatment group (see also Konings and Vandenbussche, 2008; Pierce, 2011).

The estimation specification at the product level takes the following form

$$
\begin{aligned}
y_{p t}= & \beta_{1} \text { Treatment }_{p} \times \text { Post }_{p t}^{1}+\beta_{2} \text { Preliminary Duties }_{p t} \times \text { Post }_{p t}^{2} \\
& +\beta_{3} \text { Final Duties }_{p t} \times \text { Post }_{p t}^{3}+\lambda_{p}+\lambda_{t}+\varepsilon_{p t},
\end{aligned}
$$

where $y_{p t}$ is the outcome variable (i.e., the logarithm of export volume, the logarithm of the number of exporters, the logarithm of export price, and the logarithm of total export volume to countries other than the U.S.) for product $p$ in month $t$; Treatment is a dummy variable taking the value of 1 if product $p$ belongs to the treatment group (i.e., is being investigated for dumping) and 0 otherwise; Preliminary Duties $s_{p t}$ and Final Duties $s_{p t}$ are the antidumping duties imposed upon affirmative preliminary and final determinations, respectively; $\lambda_{p}$ is the product dummy capturing all time-invariant product characteristics; $\lambda_{t}$ is the month dummy capturing effects common to all products in the same month; and $\varepsilon_{p t}$ is an error term. The three time variables corresponding to the three dates of interest in the antidumping investigation process are constructed as follows.

$$
\begin{aligned}
& \text { Post }_{p t}^{1}=\left\{\begin{array}{ll}
1 & \text { if } t \in\left[t_{p 0}, t_{p 1}\right) \\
0 & \text { otherwise }
\end{array},\right. \\
& \text { Post }_{p t}^{2}=\left\{\begin{array}{ll}
1 & \text { if } t \in\left[t_{p 1}, t_{p 2}\right) \\
0 & \text { otherwise }
\end{array},\right.
\end{aligned}
$$

and

$$
\text { Post }_{p t}^{3}=\left\{\begin{array}{ll}
1 & \text { if } t \geq t_{p 2} \\
0 & \text { otherwise }
\end{array},\right.
$$


where $t_{p 0}$ is the date of initiation (specifically, the month in which the case is initiated) for product $p$; $t_{p 1}$ is the date of the preliminary ITC determination for product $p$; and $t_{p 2}$ is the date of the final ITC determination for product $p$. To deal with the potential heteroskedasticity and serial correlation, we cluster standard errors at the product level (see Bertrand, Duflo, and Mullainathan, 2004).

The estimation specifications for the firm-product level analysis are similar to specification (1), with the only change being replacement of the outcome variable $y_{p t}$ and Final Duties $_{p t}$ at the product level with that at the firm-product level. ${ }^{4}$

The coefficients of interest in this study are $\beta_{1}, \beta_{2}$, and $\beta_{3}$. The consistent estimation of $\left\{\beta_{1}, \beta_{2}, \beta_{3}\right\}$ hinges upon the assumption that the difference in the error term of the pre- and post-antidumping investigation period for the treatment group is the same as the corresponding one for the control group, i.e.,

$$
E\left[\triangle \varepsilon_{p t} \mid \text { Treatment }_{p}=1\right]=E\left[\triangle \varepsilon_{p t} \mid \text { Treatment }_{p}=0\right] .
$$

With panel data for multiple periods and multiple groups, we conduct two validity checks following Angrist and Pischke (2009) and Imbens and Wooldridge (2009): a check on whether there is any difference in time trends between the treatment and control groups before the initiation of an antidumping investigation, and allowing for the possibility that different HS-6 digit products have different time trends. For more details, please see Section 5.6.

\section{Data}

Our study draws on data from two sources. The first is China Customs data for the 2000-2006 period, which are generously provided by China Data Center at Tsinghua University, Beijing. ${ }^{5}$ This data set covers the monthly import and export transactions of every Chinese exporter and importer, specifically including product information (classified at the Chinese HS- 8 digit level), trade volume, trade value, identity of Chinese exporter or importer, and export destinations or importing countries. As our analysis focuses on antidumping cases brought by the U.S. against Chinese exporters, we extract information about monthly export transactions by Chinese exporters to the U.S.

The second data source is the Global Antidumping Database (GAD) of the World Bank, covering all antidumping cases around the world from 1980 to 2010 (Bown, 2010). The GAD has detailed information on each antidumping case, such as product information (classified at the U.S. HS-10 digit level), initiation date, preliminary determination

\footnotetext{
${ }^{4}$ Note that there are no within-product, across-firms variations in the preliminary antidumping duties.

${ }^{5}$ The year 2000 is the earliest year when China Customs released this monthly trade transaction data set, whereas the year 2006 is the latest year for which the data set is available to the authors.
} 
dates and duties, and final determination dates and duties. For our analysis, we collect information on all U.S. antidumping cases against China during our sample period (i.e., 2000-2006).

We match the two data sets (i.e., the China Customs data and the GAD data) at the HS-6 digit level, the most disaggregated level at which the two data sets are comparable. By doing so, we essentially aggregate export information in the China Customs data from the Chinese HS-8 digit level to the HS 6-digit level, and aggregate U.S. antidumping cases (against China) from the U.S. HS-10 digit level to the HS 6-digit level.

There are 47 U.S. antidumping cases against Chinese exporters during the 2000-2006 period. Two cases (one in early 2000 and the other in late 2006) are dropped as the preor post-antidumping period is not long enough for us to carry out DID estimation. Three further cases are also dropped because they overlap with earlier antidumping cases in the same HS-6 product categories (see also Konings and Vandenbussche, 2008). Twentyeight cases out of the remaining 42 ended with affirmative final ITC determinations (referred to as successful cases); 5 out of the 6 cases that had affirmative preliminary ITC determinations received negative final ITC determinations (referred to as unsuccessful cases) and 1 was withdrawn before the final ITC determination (referred to as withdrawn cases); finally, 8 cases were either withdrawn before preliminary ITC determinations or given negative preliminary ITC determinations (referred to as terminated cases). As our analysis looks into the effects of antidumping at the three different stages of the antidumping investigation (i.e., initiation, preliminary ITC determination, and final ITC determination), we focus on the sample of 28 successful cases in the main analysis. For a robustness check, we include the unsuccessful and withdrawn cases, and find our results remain qualitatively the same. ${ }^{6}$ See Table A.2 of the Appendix for a list of all the U.S. antidumping cases investigated against Chinese exporters over the 2000-2006 period.

Among the 28 successful antidumping cases, the mean value of antidumping duties is $157 \%$. However, there are substantial variations across product categories and across firms within the same product categories. Specifically, the median value of antidumping duties across products is $134 \%$ while the values for the 10th and 90th percentiles are $44 \%$ and $306 \%$, respectively. Within the same product categories, respondents face much lower antidumping duties (i.e., 64\% lower) than their nonrespondent counterparts.

The matched panel data from 2000 to 2006 contain 16,302 product-month level observations and 800,079 firm-product-month level observations. Among the 346 HS-6 digit product categories included in the matched data, 81 product categories were successfully

\footnotetext{
${ }^{6} \mathrm{We}$ also experiment with other possible robustness checks involving changes in the sample of cases, such as combining the 28 successful cases with the only withdrawn case (as withdrawn cases are generally cases that end with affirmative final ITC determinations) and combining the 28 successful cases with the 5 unsuccessful cases (as they all have dates for preliminary and final ITC determinations), and find qualitatively similar results.
} 
subject to antidumping duties. ${ }^{7}$ However, as antidumping investigations take place at the U.S. HS-10 digit level (similar to the Chinese HS-8 digit level), one may be concerned about a potential aggregation bias, that is, some adjustments taking place at the HS-10 digit level may not be detected at the HS-6 digit level. To address this potential concern, we conduct a robustness check by examining whether there are differential responses for HS-6 digit products with different numbers of HS-10 digit products. The premise is that adjustments at the HS-10 digit level should be relatively easier for those HS-6 digit products with more HS-10 digit products. Hence, a finding of insignificant differential responses would indicate that the aggregation bias is not a serious concern in our setting.

One of the focuses of this paper is to investigate the possible heterogeneous response to antidumping investigations in light of the recent literature on firm heterogeneity and trade. We first follow the method developed by Ahn, Khandelwal, and Wei (2011) for the same data by dividing firms in our sample into trade intermediaries and direct exporters. Specifically, trade intermediaries are identified as firms whose names contain Chinese characters ( i.e., "Jinchukou", "Jingmao", and "Maoyi") with the English-equivalent meaning of importer, exporter, and/or trading. The validity of this identification approach comes from the legacy of China's centrally-planned system and the reform strategy adopted after 1978. Specifically, to insulate the Chinese domestic market from international competition, the Chinese central government only authorized 12 state-owned enterprises to conduct exports and imports in the pre-reform era (i.e., 1949-1978). These aforementioned Chinese characters were used for easy identification and regulation. Since 1978, China has adopted a gradualism approach in liberalizing its economy, with an increasing number of firms allowed to conduct foreign trade. However, the tradition of using self-revealing names for trading corporations has continued in the post-reform era. Ahn, Khandelwal, and Wei (2011) find that firms identified as trade intermediaries by this method are indeed very different from direct exporters in terms of the trading volume, product categories, and export destinations.

Furthermore, we divide the sample of direct exporters into two types: single- and multi-product exporters. Specifically, an exporter is identified as a single-product exporter if it exports only one HS-6 digit product to the U.S. before the initiation of an antidumping investigation (referred to as Single-product exporters to the U.S.). However, there is a potential concern that some of these single-product exporters may export other products to countries other than the U.S. To relieve this concern, we conduct a robustness check by excluding those firms that export other products to countries other than the U.S. (the resulting subset of Single-product exporters to the U.S. is referred to as Single-product exporters to the U.S. and worldwide).

For products subject to antidumping investigations during our sample period, there were 9,356 exporters before the initiation of antidumping investigations. Of these firms,

\footnotetext{
${ }^{7}$ Note that one antidumping case may involve several HS-6 digit product categories.
} 
3,465 were trade intermediaries. Among the remaining 5,891 direct exporters, 627 were single-product direct exporters to the U.S., and 265 were single-product direct exporters to the U.S. and worldwide.

As the monthly data are quite noisy, we conduct a robustness check using quarterly instead of monthly data. Meanwhile, to further alleviate the concern over outlying observations, we experiment by excluding the observations at the top and bottom $1 \%$ of the corresponding outcome variables. Furthermore, the possibility that other countries may conduct antidumping investigations into the same products as those investigated by the U.S. in the same period may confound our results. To alleviate this concern, we experiment by excluding cases (i.e., 4 in total) also being investigated for dumping in other countries. Finally, as some of China's exporters conduct processing trade with U.S. companies and a significant percentage of China's exporters are foreign-owned enterprises operating in China, we conduct robustness checks by excluding processing trade from our sample and by focusing on the sub-sample of China's indigenous exporters.

\section{$5 \quad$ Empirical Findings}

In this section, we first provide five baseline empirical findings regarding how exporters respond to antidumping investigations in sub-sections 5.1-5.5. We then present a series of robustness checks on the validity of our DID estimation and other econometric concerns in sub-section 5.6.

\subsection{Product-Level Quantity Response}

We begin by examining the possible trade-dampening effect of antidumping investigations at the product level. Before presenting regression results regarding equation (1), we plot time trends of export volume for the treatment and control groups over the pre- and post-antidumping investigation periods in Figures 1a-1b. Figure 1a shows the results obtained using Control Group 1, and Figure 1b shows the results obtained using Control Group 2. Each figure contains three vertical dotted lines, from left to right, marking respectively, the dates of the initiation of the antidumping investigation, the preliminary ITC determination, and the final ITC determination.

A few results emerge from these figures. First, there is clearly an upward trend in the export volume of both the treatment and control groups before the initiation of the antidumping investigation, consistent with the general trend of increasing Chinese exports to the U.S. in recent decades. Second, and more importantly, before the initiation of the antidumping investigation, the treatment and control groups do not exhibit any differential time trends, implying that there is no selection on the outcome variable and hence alleviating concerns about the validity of our DID estimation. Third, antidump- 
ing investigations have a clear dampening effect on the export volume of the treatment group, consistent with the literature (e.g., Prusa, 2001; Vandenbussche and Zanardi, 2010; Egger and Nelson, 2011). Fourth, regarding the three different stages of antidumping investigations, we observe significant effects exerted by both affirmative preliminary and affirmative final ITC determinations, but not by the initiation of the investigation. ${ }^{8}$ Note that the decline in export volume does not take place immediately after the affirmative determinations. One possible reason is that some existing contracts between U.S. importers and Chinese exporters need to be fulfilled despite the issuance of the affirmative determinations.

Regression results corresponding to equation (1) are reported in Columns 1 and 2 of Table 1, where Control Group 1 and Control Group 2 are used, respectively. We find that both the preliminary duties and the final duties have negative and statistically significant effects on export volume at the product level. In terms of the magnitude, a one-standard-deviation increase in the preliminary (final) duties leads to a decrease in export volume of around $23 \%$ (25\%) during the period between the preliminary and final ITC determinations (from the date of the final ITC determination to the end of our sample period). ${ }^{9}$

\subsection{Extensive Versus Intensive Margins}

Now that we have documented the substantial dampening effect that antidumping investigations have on export volume, we next anatomize this effect by investigating its underlying mechanism. Specifically, we look at the effect of antidumping investigations on both the number of exporters to the U.S. (the extensive margin effect) and the average export volume for surviving exporters (the intensive margin effect).

Figures $2 \mathrm{a}-2 \mathrm{~b}$ plot time trends of the number of exporters for the treatment and control groups over the pre- and post-antidumping investigation periods. Clearly, antidumping investigations cause a significant decrease in the number of exporters. Specifically, between the initiation of an antidumping investigation and the preliminary ITC determination, there is barely any change in the number of exporters. However, after an affirmative preliminary ITC determination, the number of exporters decreases sharply, followed by another substantial decrease upon the release of an affirmative final ITC determination.

Figures 3a-3b present time trends of export volume for surviving exporters and their control groups over the pre- and post-antidumping investigation periods. There is a slight

\footnotetext{
${ }^{8}$ In contrast, Staiger and Wolak (1994) find significant effects at the initition of antidumping investigations for 450 U.S. manufacturing industries from 1958 to 1985.

${ }^{9}$ Prusa (2001) shows that antidumping duties cause the value of imports to fall by an average of 30-50\% while Egger and Nelson (2011) find a modest effect of antidumping duties using a structural estimation of the gravity model.
} 
decline in the export volume of surviving exporters compared with their control groups upon affirmative ITC antidumping determinations.

Regression results regarding the extensive margin effects of antidumping investigations are reported in Columns 1-2 of Table 2. We find both $\beta_{2}$ and $\beta_{3}$ to be negative and statistically significant at the $1 \%$ level. These results are consistent with the findings revealed in Figures 2a-2b, implying that antidumping investigations exert a strong extensive margin effect. In terms of economic magnitude, an one-standard-deviation increase in the preliminary duties leads to a decrease in the number of exporters by around $10 \%$ during the period between the preliminary and final ITC determinations. Likewise, a one-standard-deviation increase in the final duties leads to a decrease in the number of exporters by around $7 \%$ from the final ITC determination until the end of our sample period.

In Columns 3-4 of Table 2, we report regression results regarding the intensive margin effects of antidumping investigations. Antidumping duties (i.e., $\beta_{2}$ and $\beta_{3}$ ) have negative and statistically significant impacts on the export volume per exporter. These results are consistent with the findings revealed in Figures 3a-3b. In terms of economic magnitude, a one-standard-deviation increase in the preliminary (final) duties leads to a decrease in export volume per exporter by around $7 \%$ (7\%) during the period between the preliminary and final ITC determinations (from the final ITC determination until the end of our sample period).

\subsection{Heterogeneous Responses}

In the previous section, we document that much of the trade-dampening effect of antidumping investigations is attributed to the sharp decrease in the number of exporters in response to both the affirmative preliminary and affirmative final ITC determinations. We are interested in knowing what kinds of exporters are more likely to exit the export market at these two important dates in the antidumping investigation process. A recent development in the trade literature centers on how firm heterogeneity, particularly firm productivity, affects exporting behavior. Hence, we start by looking at whether more productivity exporters are less likely to exit after the affirmative antidumping determinations. Meanwhile, more recent studies in international trade have gone beyond firm productivity by looking at different types of exporters, i.e., trade intermediaries versus direct exporters, and single-product versus multi-product direct exporters. Following these

lines of the literature, we also look at the possible differences in exiting likelihood among these types of exporters. 


\subsubsection{Firm Productivity}

Unfortunately, due to data limitations, we do not have the information from the China Customs data to measure firm productivity directly. ${ }^{10}$ Instead, we use export volume as a proxy for firm productivity. ${ }^{11}$

Indeed, by merging the China Customs data with China's annual surveys of manufacturing firms (which covers $25.6 \%$ of the observations in the China Customs data), we find a positive and significant correlation between export volume and firm productivity (i.e., estimated coefficient is 0.02 with a p-value of 0.08 ).

An exporter (i.e., any firm that exported the affected HS-6 digit products before the antidumping investigations) is classified as exiting the U.S. market if it stopped exporting the affected products after the affirmative final ITC determination (denoted as Exit). Such exiting behavior may start immediately upon the initiation of antidumping investigations, between the affirmative preliminary and affirmative final ITC determinations, or after the affirmative final ITC determination. The regression specification is as follows:

$$
\text { Exit }_{f p}=\gamma \cdot \text { Export } \text { Volume }_{f p}+\lambda_{p}+\varepsilon_{f p}
$$

where the inclusion of product dummy $\left(\lambda_{p}\right)$ allows us to compare exit likelihood among exporters within a narrowly-defined product category (i.e., HS-6 product level). Specification (6) is estimated using the Probit model.

As Column 1 of Table 3 shows, among all exporters, exporters with larger export volume are less likely to exit. This holds for the subsample of direct exporters (i.e., Column 1 of Table 4). Moreover, the negative impact of firm productivity on exit likelihood remains when we control for the different type of exporters (trade intermediaries versus direct exporters in Column 2 of Table 3, and single-product versus multi-product direct exporters in Column 2 of Table 4).

Recall that respondents face lower antidumping duties than non-respondents. In addition, we find that firms with larger export volume are more likely to respond to U.S. antidumping investigations (i.e., estimated coefficient is 0.007 with a t-statistic of 3.69). It could be that as larger firms are more incentivized to stay, they are more responsive to antidumping investigations, thereby enjoying lower antidumping duties and becoming less likely to exit. To control for this potential channel, we include firm-specific duties in

\footnotetext{
${ }^{10}$ The China Customs data have information about the output (i.e., export volume and export value), but not about the inputs (i.e., labor, capital, and materials), which prohibits us from calculating firm productivity.

${ }^{11}$ Export price is not a good proxy for firm productivity for a number of reasons. First, more productive exporters may charge lower prices due to their lower production costs, but they could also charge higher prices given the higher quality of their goods. Second, higher export prices may diminish the likelihood of antidumping duties being imposed on a firm, directly influencing its exit likelihood, which compounds the results using export price as a proxy for firm productivity.
} 
Column 3 of Tables 3 and 4 . Clearly, the negative effect of firm productivity on survival remains robust to this additional control, suggesting that our findings are not mainly driven by the difference in antidumping duties.

Our results suggest that more productive exporters are more likely to survive the negative shocks (brought out by antidumping investigations), which can be explained by the firm heterogeneity literature. Specifically, in the case of a per-period fixed cost of exporting, the Melitz (2003) model shows that when facing negative shocks induced by antidumping investigations, exporters experience a fall in their revenue. The less productive exporters are unable to recover the per-period fixed cost of exporting and are thereby forced to exit from the U.S. market. Without fixed cost of exporting, the Melitz and Ottaviano (2008) model suggests that the negative shock causes a decrease in exporters' markups, resulting in the less productive ones incurring losses and, hence, exiting the U.S. market.

\subsubsection{Trade Intermediaries versus Direct Exporters}

Table 3 also reports regression results regarding the differential likelihood of exiting the U.S. market between trade intermediaries and direct exporters, with the regressor of interest being Trade Intermediary, which takes the value of 1 if the exporter is a trade intermediary and 0 otherwise.

As Columns 2 and 3 of Table 3 show, Trade Intermediary has negative and statistically significant estimated coefficients, suggesting that trade intermediaries are less likely to exit the U.S. market for the affected products than direct exporters. These results are robust to the control of firm productivity (proxied by export volume), and the control of firm-specific final antidumping duties.

Our findings suggest that trade intermediaries and direct exporters are rather different in their exporting behavior. Instead of arbitrarily picking theories to explain their differences, we strive to offer an explanation that is grounded in observed differences between trade intermediaries and direct exporters in the data. Specifically, trade intermediaries are more multi-market and multi-product oriented than direct exporters. On average (across all affected products), 91\% of trade intermediaries sell products other than the affected products, whereas the corresponding number for direct exporters is $81 \%$. Meanwhile, $68 \%$ of trade intermediaries sell the affected products to countries other than the U.S., whereas the corresponding number for direct exporters is $64 \%$. The multi-market and multi-product nature of trade intermediaries equips them with more capabilities to tap into their reserves in other products and other markets and hence to cross-subsidize their affected products in the U.S., which helps them weather the storms generated by antidumping investigations, compared with direct exporters. 


\subsubsection{Single-Product versus Multi-Product Direct Exporters}

In Table 4, we examine the relative likelihood of exit from the U.S. market for the affected products between single- and multi-product direct exporters, where the key regressor is Single Product taking the value of 1 if the direct exporter is a single-product direct exporter to the U.S. and 0 otherwise.

As Columns 2 and 3 of Table 4 reveal, Single Product has a positive and statistically significant estimated coefficient, indicating that single-product direct exporters are more likely than their multi-product counterparts to exit the U.S. market for the affected products. This can be explained by multi-product direct exporters' greater ability to cross-subsidize the affected products, compared with their single-product counterparts, which is in line with our aforementioned explanation of the differential likelihood of exiting between trade intermediaries and direct exporters.

In unreported results (available upon request), we find a higher likelihood of exiting by multi-product direct exporters in response to affirmative preliminary ITC determinations, but a higher likelihood of existing by single-product direct exporters in response to affirmative final ITC determinations. One possible explanation for such contrasting exiting behavior between single- and multi-product direct exporters at different stages of antidumping investigations is the uncertainty regarding the final ITC determination, even upon affirmative preliminary ITC determinations (e.g., 18\% of the affirmative preliminary ITC determinations in our sample ended up with negative final ITC determinations). Such uncertainty on the outcome of the final ITC determination can generate differing exiting behavior across exporters. Specifically, the weakest exporters exit immediately in response to the affirmative preliminary ITC determinations, whereas the strongest exporters stay throughout the whole antidumping investigation process and even after the affirmative final ITC determinations. Interestingly, those in the middle choose to stay after the affirmative preliminary ITC determinations but decide to exit in response to the affirmative final ITC determinations. Combined, it implies that single-product direct exporters are relatively more concentrated in the middle range of export volume and multi-product direct exporters are scattered in the lowest and highest ranges of export volume; that is, multi-product direct exporters are more heterogeneous than their single-product counterparts. Indeed, we find that the average coefficient of variations for single-product direct exporters is 0.23 , whereas the corresponding number for multiproduct direct exporters is 0.32 . Intuitively, multi-product direct exporters in the highest range of export volume could represent exporters producing the affected products as their core products while selling other peripheral products, whereas those in the lowest range of export volume are just the opposite. 


\subsection{Price Response}

We now analyze the possible price responses of antidumping investigations; that is, the effect on average F.O.B. export prices for surviving exporters.

Figures $4 \mathrm{a}-4 \mathrm{~b}$ present time trends of export prices of affected products among surviving exporters and those of their control groups over the pre- and post-antidumping investigation periods. We find no substantial difference in the time trends of export prices between the treatment and control groups either before or after an antidumping investigation.

Regression results regarding the effects of antidumping investigations on the export prices of surviving exporters are reported in Columns 1-2 of Table 5. We find that surviving exporters have statistically significant, albeit small in magnitude (around $2 \%$ ), price increases when preliminary antidumping duties are imposed, and there is no further price increase after the imposition of final antidumping duties.

\subsection{Trade Deflection Response}

In this subsection, we examine whether Chinese exporters respond to U.S. antidumping investigations by diverting their exports to countries other than the U.S., namely the trade deflection response (e.g., Bown and Crowley, 2007).

Figures 5a-5b present time trends of total export volume to other countries of affected HS-6 digit products and their control groups over the pre- and post-antidumping investigation periods. There is no clear differential time trend of total export volume to other countries between the treatment and control groups either before or after an antidumping investigation. The regression results reported in Table 6 reaffirm the findings revealed in Figures 5a-5b.

In unreported tables (available upon request), we investigate possible trade deflection to Canada or OECD countries (that may share similar economic structures as the U.S.), and among different types of Chinese exporters (i.e., trade intermediaries, single-product direct exporters, and multi-product direct exporters). None of these exercises yields any significant effects of antidumping investigations on trade deflection.

One possible explanation for the consistent lack of trade deflection is that the fixed costs of exporting are country-specific (e.g., Chaney, 2008; Arkolakis, 2010), as a result of which the decision to enter each foreign market is independent. Indeed, we find in our data that Chinese exporters to the U.S. are heavily weighted in the U.S. market, i.e., about $63 \%$ of these exporters' world export revenues come from the U.S. market. 


\subsection{Robustness Checks}

In this section, we conduct a series of robustness checks on the aforementioned DID estimation results for all the relevant outcome variables examined in sub-sections 5.1-5.5 (i.e., quantity response, extensive and intensive margin effects, price response, and trade deflection response).

First, the validity of our DID estimation hinges upon the assumption that the treatment and control groups are comparable before the treatment occurs. To check specifically whether there is any difference in time trends between the treatment and control groups before the initiation of an antidumping investigation, we conduct a robustness check by including an additional regressor, Treatment $p \times \operatorname{Pre}_{p t}$, where $\operatorname{Pre}_{p t}=1$ if $t \in\left[t_{p 0}-12, t_{p 0}\right)$ and 0 otherwise. The estimation results are summarized in Table A.3 of the Appendix. Clearly, there is no evidence of any differential time trends between the treatment and control groups before the initiation of an antidumping investigation, thus lending support to the validity of our DID estimations. Our main findings on the effects of antidumping investigations also remain robust.

Second, one may be concerned that products in the treatment group and their counterparts in the control group may follow different time trends. To address this concern, we allow for product-specific time trends in our estimation, i.e., the inclusion of additional controls $\lambda_{p} \times t$. The estimation results are reported in Table A.4 of the Appendix. Our main findings on the effects of antidumping investigations remain robust to the inclusion of product-specific time trends, again implying that our DID estimations are valid.

Third, to alleviate the concern that our monthly data could be noisy, as not all exporters export to the U.S. every month, we conduct a robustness check by using quarterly instead of monthly data (i.e., aggregation of monthly export transactions to the quarterly level). The regression results are reported in Table A.5 of the Appendix. In addition to the statistically significant effects of antidumping investigations reported earlier, a final ITC determination has a negative and significant (at the $5 \%$ level) impact over the export volume of surviving exporters (i.e., providing limited evidence supporting the intensive margin effect). In addition, the magnitudes of the effects for the sample of quarterly data are much bigger.

Fourth, to further address the concern that our results may be affected by some outlying observations, we focus on a sub-sample that excludes the observations at the top and bottom $1 \%$ of the corresponding outcome variables. The regression results reported in Table A.6 of the Appendix show the robustness of our earlier findings and offer limited evidence supporting the intensive margin effect.

Fifth, note that in sub-sections 5.1-5.5, we include only successful antidumping cases (i.e., 28 cases with affirmative preliminary and affirmative final ITC determinations out of 42 antidumping cases), partly because we seek to investigate the differential effects of 
affirmative preliminary ITC determinations and affirmative final ITC determinations. To check whether our main results are sensitive to the selection of antidumping cases, we conduct a robustness check by including the five unsuccessful cases and the one withdrawn case. The regression results are reported in Table A.7 of the Appendix. Our main results regarding the effects of antidumping investigations remain qualitatively the same as those reported earlier. ${ }^{12}$

Sixth, it is possible that other countries conduct antidumping investigations into the same products as those examined by the U.S. during the same period, thereby confounding the effects of the U.S. antidumping investigations on Chinese exporters and complicating the interpretation of our results. To address this concern, we conduct a robustness check by excluding such overlapping antidumping cases (i.e., 4 cases). The regression results are reported in Table A.8 of the Appendix, and our main findings remain robust to this sub-sample.

Seventh, as some Chinese exporters conduct processing trade with U.S. companies, one may be concerned with whether antidumping investigations may have different effects on Chinese processing traders, compared with ordinary traders, which would compound our findings. To alleviate this concern, we conduct a robustness check by excluding processing traders from our sample, ${ }^{13}$ and find that our results remain robust (see Table A.9 in the Appendix). In addition, as a significant percentage of China's exporters are foreign-owned enterprises operating in China rather than indigenous firms, one may wonder if foreign-owned exporters respond differently from China's indigenous exporters. To investigate this possibility, we conduct a robustness check using the sub-sample of China's indigenous exporters, and again our results remain robust (see Table A.10 in the Appendix).

Eighth, to address the concern of a potential aggregation bias, we conduct a robustness check by including interaction terms between our key explanatory variables with the number of HS-10 digit products within each HS-6 digit product. The regression results are reported in Table A.11 of the Appendix. It is found that none of these interaction terms has any statistical significance. Meanwhile, our main findings remain robust to the inclusion of these interaction terms. These results imply that our findings are not affected by the potential aggregation bias.

Ninth, another potential concern is that the timing of antidumping investigations

\footnotetext{
${ }^{12}$ It is noted that the effects of both affirmative preliminary and final ITC determinations are smaller than those obtained using the original sample of 28 successful cases. Intuitively, as the final ITC determinations are negative for the five unsuccessful cases, the inclusion of these cases dilutes the effects of the final ITC determinations. Meanwhile, the smaller effects of the preliminary ITC determinations with the inclusion of the five unsuccessful cases suggest that the evidence for these cases is less convincing and hence the limited influence.

${ }^{13}$ In the Customs data, there is information regarding the nature of trade, such as ordinary trade and different types of processing trade (including processing exports with assembly, processing exports with imported materials, foreign aid, compensation trade, etc). In this robustness check, we only include ordinary trade.
} 
may coincide with other shocks to the trade environment, thereby contaminating the effects of antidumping investigations. To alleviate such concerns, we consider two important trade shocks that happened during our sample period. The first is the safeguard investigations conducted by the U.S. government against Chinese exports. During the sample period (i.e., 2000-2006), there were five safeguard investigations against Chinese exports, but only two involved products in either our treatment or control groups, both of which ended up with negative final determinations. Nonetheless, to isolate the effects of antidumping investigations, we control for a dummy variable indicating the period of safeguard investigations in Table A.12. The second shock was China's accession into the WTO by the end of 2001, which led to a reduction in China's import tariffs and a more competitive domestic market, which may have affected the exporting behavior of Chinese firms. ${ }^{14}$ If the timing of China's progressive tariff reduction coincides with that of U.S. antidumping investigations, it would compound the investigations' effects. To address a possible WTO effect, we include an additional control for China's import tariffs in Table A.13. Our main findings regarding the effects of antidumping investigations remain robust to the control of these two important trade shocks.

Tenth, the aforementioned exercises give us the average effects of antidumping investigations. To explore potential heterogeneous effects across products, we consider a key difference among products; namely, the elasticity of import substitution. Specifically, we interact our regressors of interests with the elasticity of substitution at the HS-6 product level (data obtained from Broda and Weinstein, 2006; see also Nizovtsev and Skiba, 2010). The estimation results reported in Table A.14. reveal little differential effects of antidumping investigations across products with different elasticity of import substitution. This can be explained by the limited variations in the elasticity of import substitutions of Chinese exports.

Eleventh, in our investigation of the differential exit likelihood between single- and multi-product direct exporters, we define the former as those selling only the concerned product to the U.S. market. It is possible, however, that these single-product direct exporters may sell other products to countries other than the U.S. In other words, these single-product direct exporters are arguably multi-product direct exporters in a broader sense. To better delineate the difference between single- and multi-product direct exporters, we adopt a stricter definition of the former, i.e., Single-product exporters to the U.S. and worldwide, and carry out a robustness check on Table 4. The regression results are reported in Table A.15 in the Appendix. Evidently, the results are similar to those in Table 4.

\footnotetext{
${ }^{14}$ Note that before China joined the WTO by the end of 2001, it already enjoyed the most-favorednation (MFN) status from the U.S. (and its other major trading partners). Hence, Chinese exporters did not see much improvement in access to the U.S. market, although the elimination of uncertainty in the annual review of the MFN status did contribute to the rise of China's export to the U.S. (Pierce and Schott, 2012).
} 


\section{Conclusion}

Antidumping measures have become a popular tool enabling governments to protect their domestic firms and industries. Much insight has been gained from a large and growing literature on how effective antidumping measures are in trade protection. An equally important but overlooked issue is how antidumping measures affect the behavior of foreign exporters, an understanding of which should help us gain a complete picture of the effects of such measures.

In this paper, we use China Customs data to investigate how Chinese exporters respond to U.S. antidumping investigations during the 2000-2006 period. To identify the effects of antidumping investigations, we use the difference-in-differences estimation strategy, which compares the outcome variables of exporters in the affected product categories with those of exporters in unaffected product categories before and after the various important stages of the antidumping investigation process.

We find that much of the trade-dampening effect of antidumping investigations at the product level operates through the extensive margin rather than the intensive margin. We also find that the bulk of the decrease in the number of exporters is exerted by less productive exporters, by direct exporters as opposed to trade intermediaries (who are more multi-market and multi-product oriented), and by single-product direct exporters as opposed to their multi-product counterparts. Combined with the findings of existing studies (e.g., Pierce, 2011) that U.S. protection through the temporary imposition of antidumping duties is more tilted toward its weaker domestic producers, our results imply that antidumping investigations may spell long-term trouble for U.S. domestic producers in their competition with Chinese exporters, as the latter becomes more productive and more multi-market and multi-product oriented through the antidumping process. 


\section{References}

[1] Ahn, JaeBin, Amit Khandelwal, and Shang-jin Wei. 2011. "The Role of Intermediaries in Facilitating Trade", Journal of International Economics 84, 73-85

[2] Angrist, Joshua D. and Jörn-Steffen Pischke. 2009. Mostly Harmless Econometrics, Princeton: Princeton University Press

[3] Arkolakis, Costas. 2010. "Market Penetration Costs and the New Consumers Margin in International Trade", Journal of Political Economy 118, 1151-1199

[4] Autor, David, David Dorn, and Gordon Hanson. Forthcoming. "The China Syndrome: Local Labor Market Effects of Import Competition in the United States", American Economic Review

[5] Bertrand, Marianne, Esther Duflo, and Sendhil Mullainathan. 2004. "How Much Should We Trust Differences-in-Differences Estimates?", Quarterly Journal of Economics 119, 249-275

[6] Blonigen, Bruce A. 2002. "Tariff-jumping Antidumping Duties", Journal of International Economics 57, 31-49

[7] Blonigen, Bruce A. and Jee-Hyeong Park. 2004. "Dynamic Pricing in the Presence of Antidumping Policy: Theory and Evidence", American Economic Review 94, 134-154

[8] Blonigen, Bruce A. and Thomas Prusa. 2003. "Antidumping", in James Harrigan and E. Kwan Choi (eds), Handbook of International Trade, Oxford: Blackwell

[9] Bown, Chad P. (2010) "Global Antidumping Database," The World Bank, available at http://econ.worldbank.org/ttbd/gad/

[10] Bown, Chad P. 2011. "Taking Stock of Antidumping, Safeguards and Countervailing Duties, 1990-2009", World Economy 34, 1955-1998

[11] Bown, Chad P. and Meredith A. Crowley. 2006. "Policy Externalities: How US Antidumping Affects Japanese Exports to the EU", European Journal of Political Economy 22, 696-714

[12] Bown, Chad P. and Meredith A. Crowley. 2007. "Trade Deflection and Trade Depression", Journal of International Economics 72, 176-201

[13] Broda, Christian and David Weinstein. 2006. "Globalization and the Gains from Variety", Quarterly Journal of Economics 121, 541-585 
[14] Chaney, Thomas. 2008. "Distorted Gravity: The Intensive and Extensive Margins of International Trade", American Economic Review 98, 1707-1721

[15] Egger, Peter and Douglas Nelson. 2011. "How Bad is Antidumping? Evidence from Panel Data", Review of Economics and Statistics 93, 1374-1390

[16] Falvey, Rodney E. and Douglas R. Nelson. 2006. "100 Years of Antidumping", European Journal of Political Economy 22, 545-553

[17] Gallaway, Michael P., Bruce A. Blonigen, and Joseph E. Flynn. 1999. "Welfare Costs of the U.S. Antidumping and Countervailing Duty Laws", Journal of International Economics 49, 211-244

[18] Imbens, Guido W. and Jeffrey M. Wooldridge. 2009. "Recent Developments in the Econometrics of Program Evaluation", Journal of Economic Literature 47, 5-86

[19] Konings, Jozef and Hylke Vandenbussche. 2008. "Heterogeneous Responses of Firms to Trade Protection", Journal of International Economics 76, 371-383

[20] Melitz, Marc. 2003. "The Impact of Trade on Intra-Industry Reallocations and Aggregate Industry Productivity", Econometrica 71, 1695-1725

[21] Melitz, Marc and Gianmarco Ottaviano. 2008. "Market Size, Trade, and Productivity", Review of Economic Studies 75, 295-316

[22] Nizovtsev, Dmitri and Alexandre Skiba. 2010. "Import Demand Elasticity and Exporter Response to Anti-Dumping Duties", working paper

[23] Pierce, Justin R. 2011. "Plant-level Responses to Antidumping Duties: Evidence from U.S. Manufacturers", Journal of International Economics 85, 222-233

[24] Pierce, Justin R. and Peter Schott. 2012. "The Surprisingly Swift Decline of U.S. Manufacturing Employment", working paper

[25] Prusa, Thomas. 2001. "On the Spread and Impact of Antidumping", Canadian Journal of Economics 34, 591-611

[26] Staiger, Robert W. and Frand A. Wolak. 1994. "Measuring Industry-Specific Protection: Antidumping in the United States", Brookings papers on Economic Activity: Microeconomics 1994, 51-103

[27] Vandenbussche, Hylke and Maurizio Zanardi. 2010. "The chilling trade effects of antidumping proliferation", European Economic Review 54, 760-777

[28] Zanardi, Maurizio. 2006. "Antidumping: A Problem in International Trade", European Journal of Political Economy 22, 591-617 
Figure 1: Time trends of export volume, product level

Figure 1a (Control group 1)

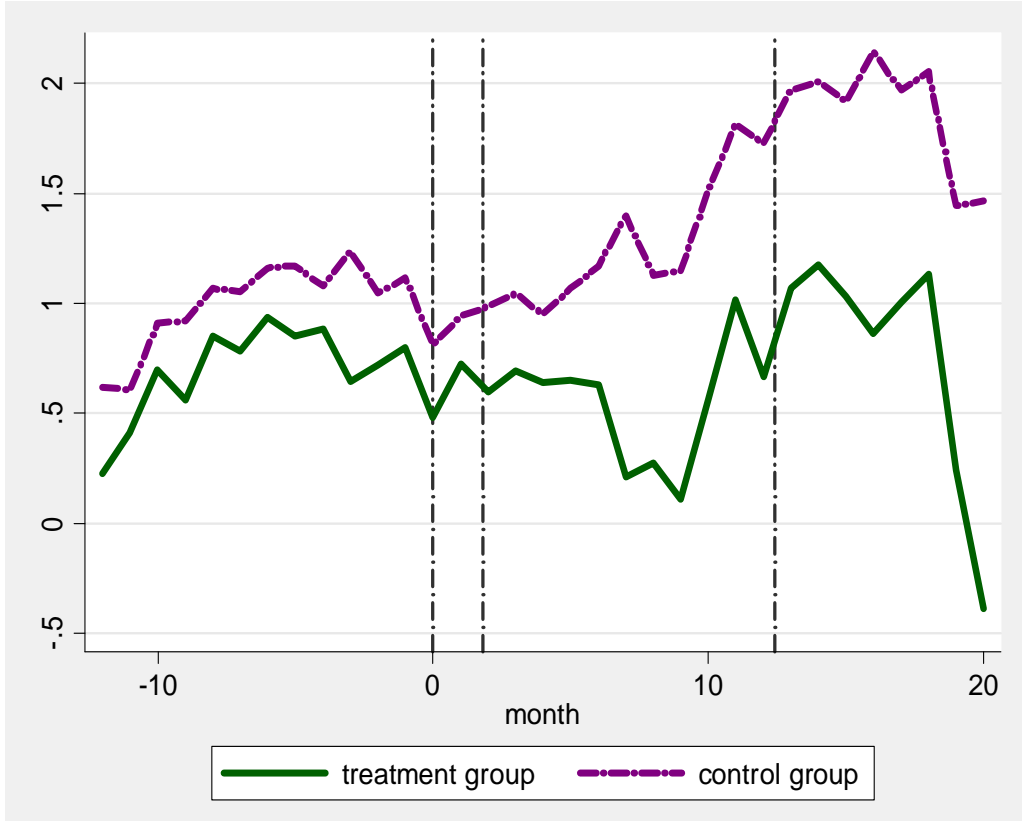

Figure 1b (Control group 2)

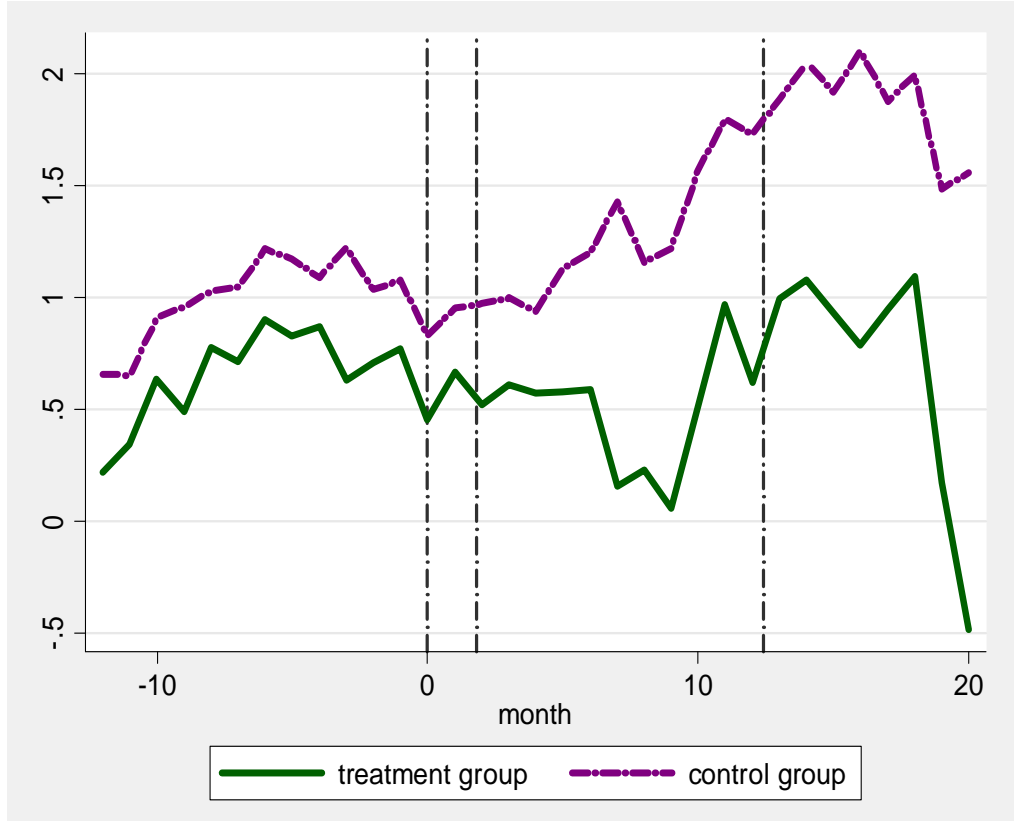

Note: The left figure reports time trends of the treatment group and control group 1, whereas the right figure reports the time trends of the treatment group and control group 2.

The three vertical lines mark respectively the date points of initiation of the antidumping investigation, the preliminary and final ITC determinations. The vertical axis is the coefficients of time dummy for the treatment and control groups. 
Figure 2: Time trends of the number of exporters

Figure 2a (Control group 1)

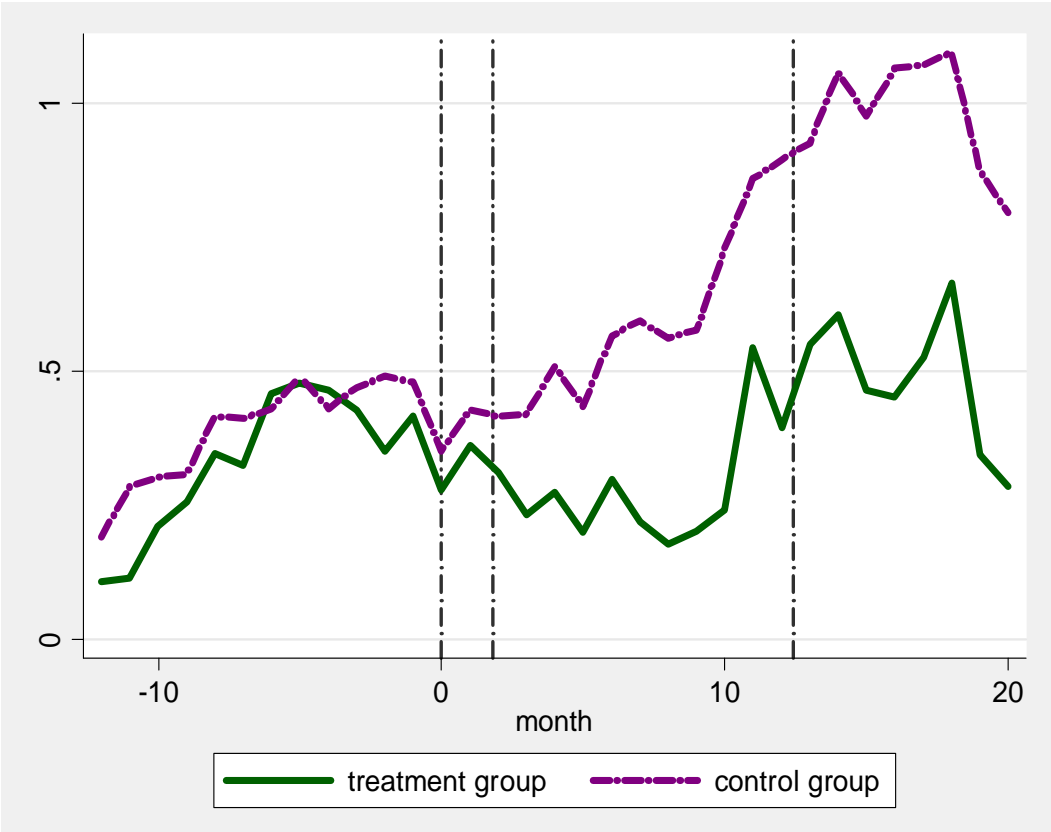

Figure 2b (Control group 2)

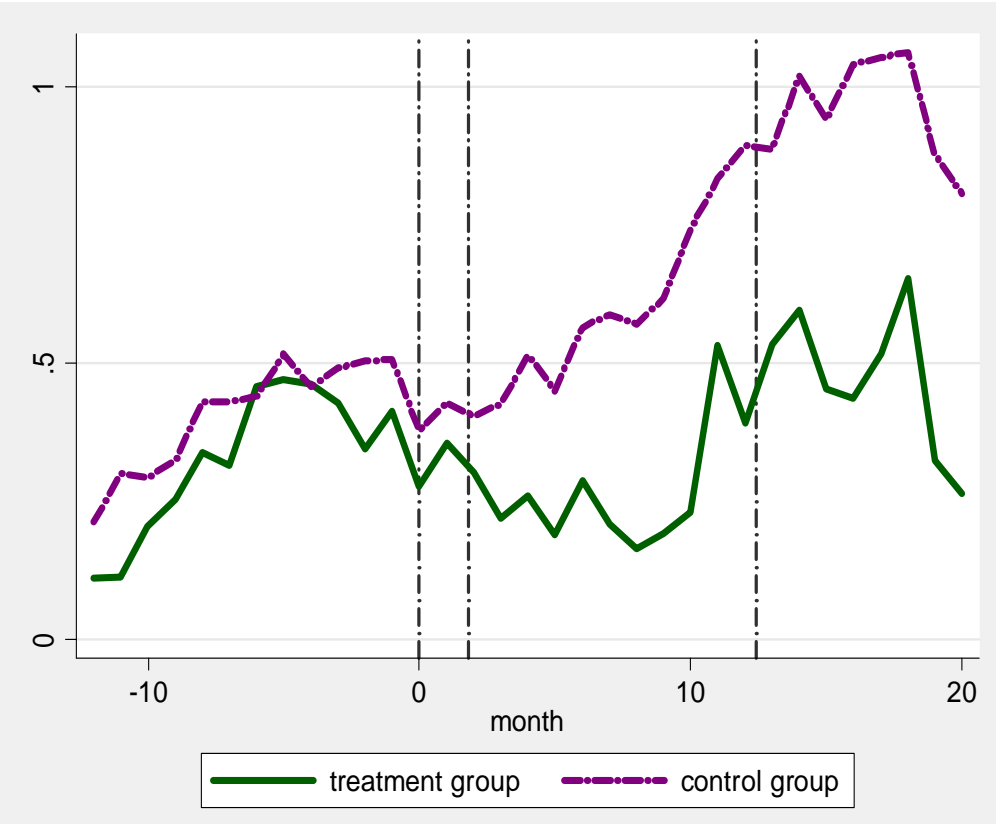

Note: The left figure reports time trends of the treatment group and control group 1, whereas the right figure reports the time trends of the treatment group and control group 2. The three vertical lines mark respectively the date points of initiation of the antidumping investigation, the preliminary and final ITC determinations. The vertical axis is the coefficients of time dummy for the treatment and control groups. 


\section{Figure3: Time trends of export volume, surviving exporters}

Figure 3a (Control group 1)

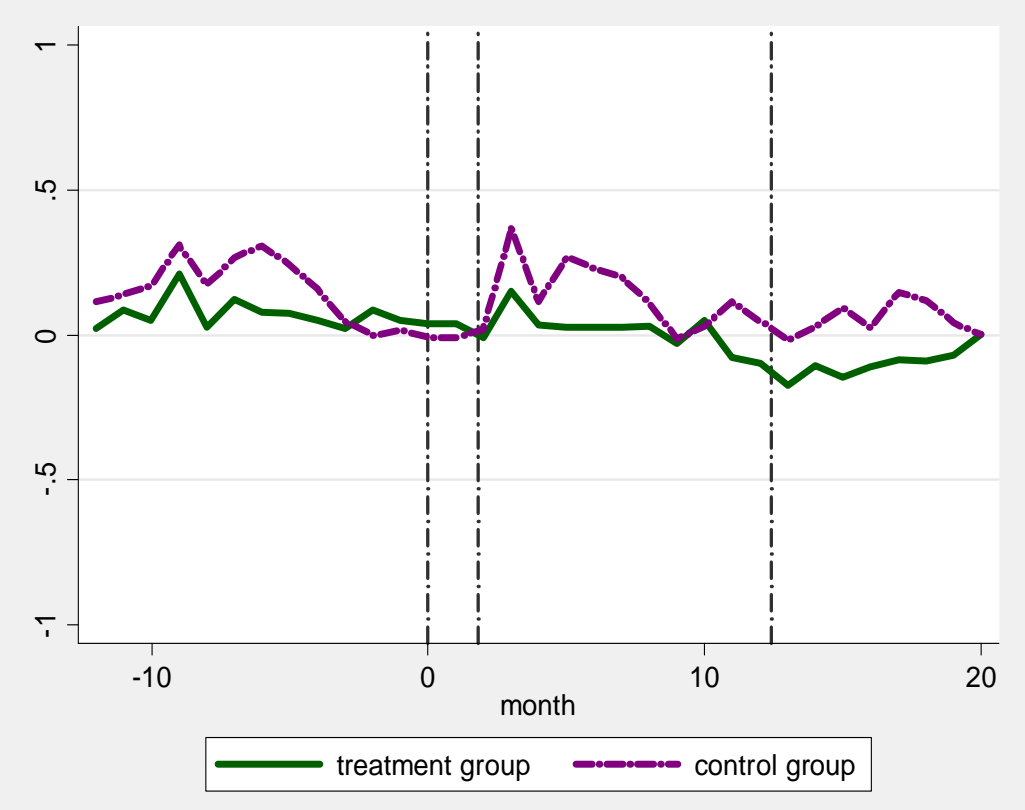

Figure 3b (Control group 2)

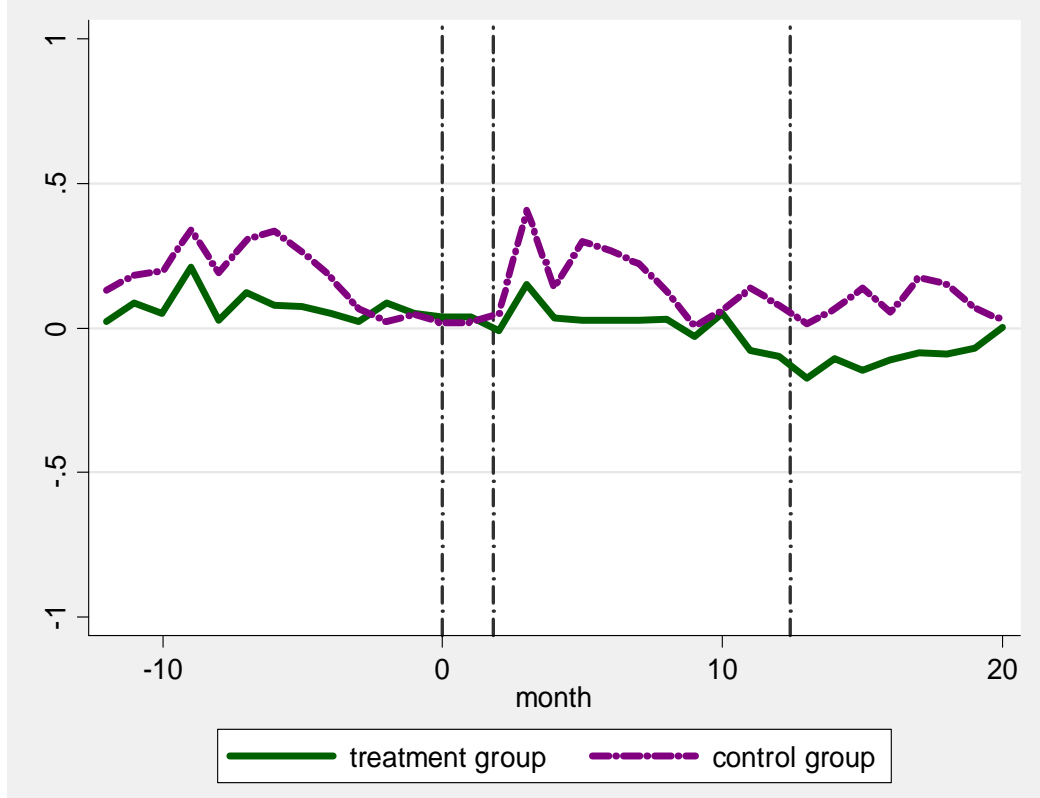

Note: The left figure reports time trends of the treatment group and control group 1, whereas the right figure reports the time trends of the treatment group and control group 2.

The three vertical lines mark respectively the date points of initiation of the antidumping investigation, the preliminary and final ITC determinations. The vertical axis is the

coefficients of time dummy for the treatment and control groups. 
Figure 4: Time trends of export prices, surviving exporters

Figure 4a (Control group 1)

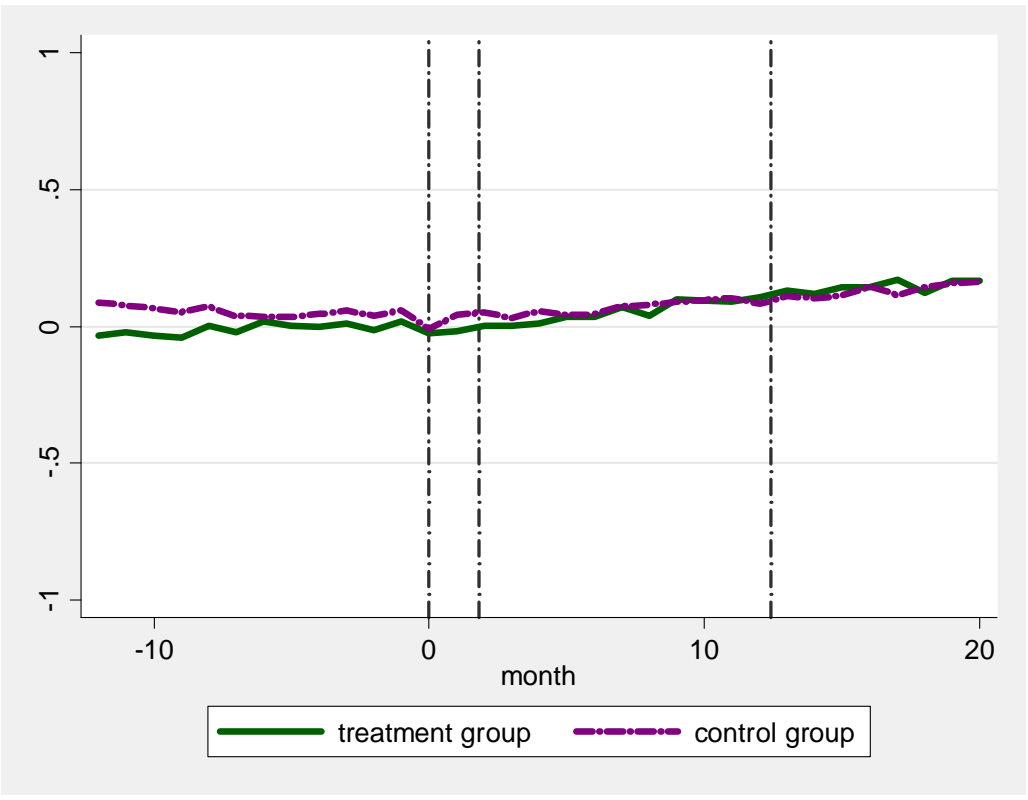

Figure ab (Control group 2)

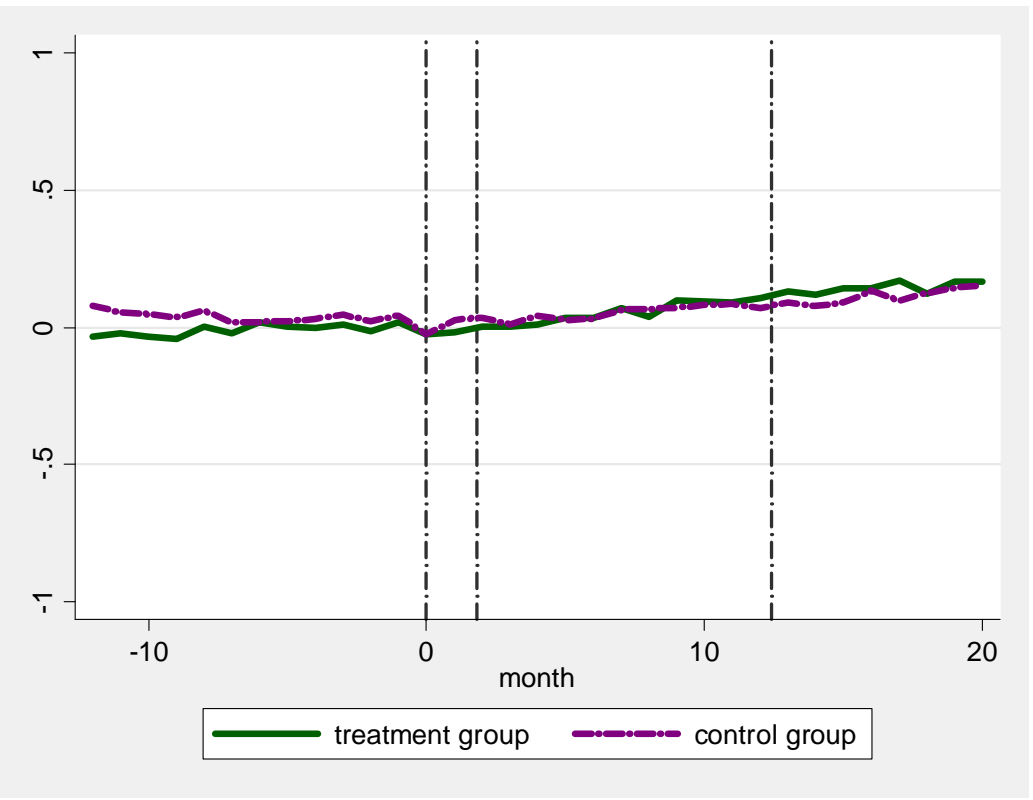

Note: The left figure reports time trends of the treatment group and control group 1, whereas the right figure reports the time trends of the treatment group and control group 2. The three vertical lines mark respectively the date points of initiation of the antidumping investigation, the preliminary and final ITC determinations. The vertical axis is the coefficients of time dummy for the treatment and control groups. 
Figure 5: Time trends of export volume to other countries, product level

Figure 5a (Control group 1)

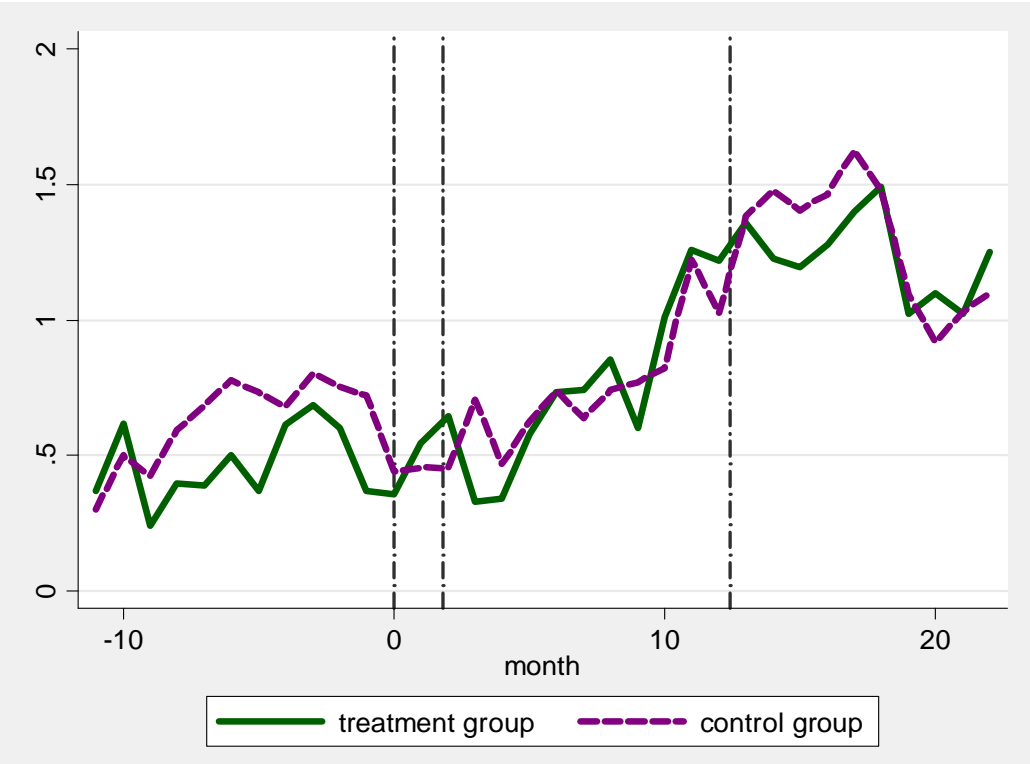

Figure $5 b$ (Control group 2)

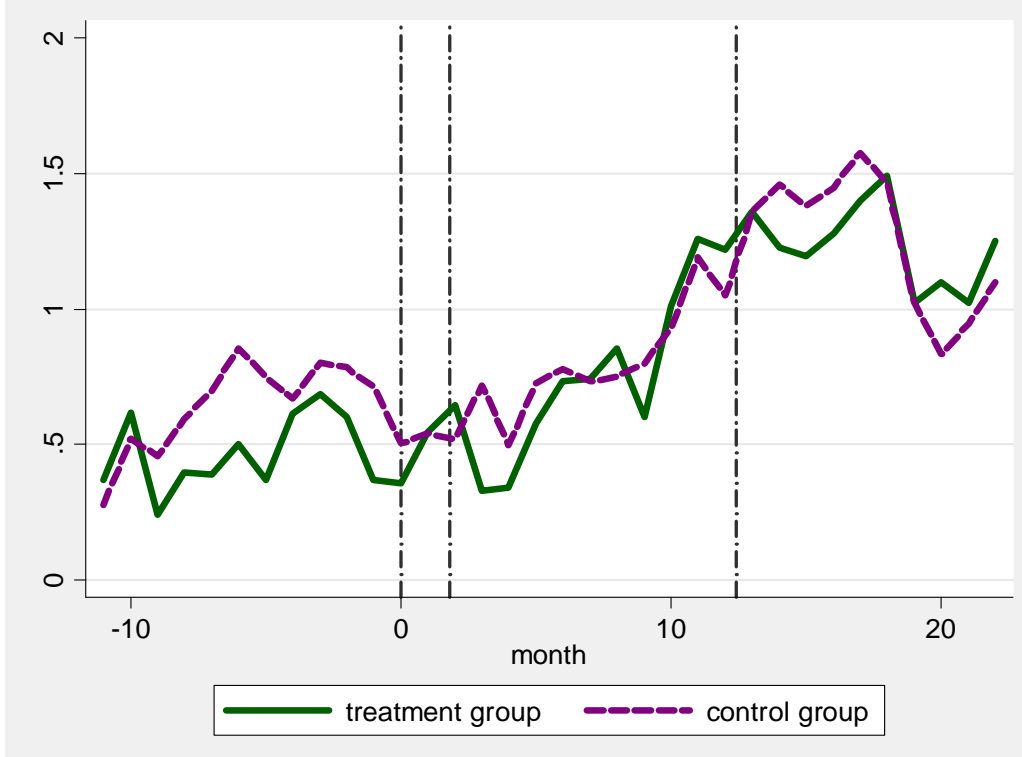

Note: The left figure reports time trends of the treatment group and control group 1, whereas the right figure reports the time trends of the treatment group and control group 2 The three vertical lines mark respectively the date points of initiation of the antidumping investigation, the preliminary and final ITC determinations. The vertical axis is the coefficients of time dummy for the treatment and control groups. 
Table 1: The effect of antidumping investigation on export volume, product level

\begin{tabular}{|c|c|c|}
\hline \multirow{3}{*}{$\begin{array}{l}\text { Dependent variable } \\
\text { Control group }\end{array}$} & & \\
\hline & \multicolumn{2}{|c|}{ Log (export volume) } \\
\hline & 1 & 2 \\
\hline \multirow[t]{2}{*}{ Initiation ( $\beta 1)$} & -0.004 & -0.021 \\
\hline & (0.158) & (0.158) \\
\hline \multirow[t]{2}{*}{ Preliminary duties( $\beta 2$ ) } & $-0.0027^{* *}$ & $-0.0028^{* *}$ \\
\hline & $(0.0007)$ & $(0.0007)$ \\
\hline \multirow[t]{2}{*}{ Final duties( $(\beta 3)$} & $-0.0060 * *$ & $-0.0061 * *$ \\
\hline & $(0.0013)$ & $(0.0013)$ \\
\hline Month fixed effects & yes & yes \\
\hline Product fixed effects & yes & yes \\
\hline Number of observations & 16,294 & 14,993 \\
\hline R-squared & 0.76 & 0.762 \\
\hline
\end{tabular}


Table 2: The effect of antidumping investigation, extensive versus intensive margins

\begin{tabular}{|c|c|c|c|c|}
\hline \multirow{5}{*}{$\begin{array}{l}\text { Specification } \\
\text { Dependent Variable } \\
\text { Sample } \\
\text { Control Group }\end{array}$} & (1) & (2) & (3) & (4) \\
\hline & \multirow{3}{*}{\multicolumn{2}{|c|}{$\begin{array}{c}\text { Extensive margin } \\
\text { Log (number of exporters) } \\
\text { Whole sample }\end{array}$}} & \multirow{3}{*}{\multicolumn{2}{|c|}{$\begin{array}{l}\text { Intensive margin } \\
\text { Log (export volume) } \\
\text { Surviving firms }\end{array}$}} \\
\hline & & & & \\
\hline & & & & \\
\hline & 1 & 2 & 1 & 2 \\
\hline \multirow[t]{2}{*}{ Initiation $(\beta 1)$} & -0.016 & -0.021 & -0.012 & 0.004 \\
\hline & $(0.037)$ & $(0.037)$ & $(0.040)$ & $(0.047)$ \\
\hline \multirow[t]{2}{*}{ Preliminary duties $(\beta 2)$} & $-0.0012^{* *}$ & $-0.0012 * *$ & $-0.0008^{* *}$ & $-0.0008 * *$ \\
\hline & $(0.0003)$ & $(0.0003)$ & $(0.0002)$ & $(0.0002)$ \\
\hline \multirow[t]{2}{*}{ Final duties( $\beta 3)$} & $-0.0022 * *$ & $-0.0022 * *$ & $-0.0015^{* *}$ & $-0.0016^{* *}$ \\
\hline & $(0.0005)$ & $(0.0005)$ & $(0.0003)$ & $(0.0003)$ \\
\hline Month fixed effects & yes & yes & yes & yes \\
\hline Product fixed effects & yes & yes & yes & yes \\
\hline Number of observations & 16,302 & 14,997 & 547,007 & 538,113 \\
\hline R-squared & 0.932 & 0.936 & 0.227 & 0.227 \\
\hline
\end{tabular}


Table 3: The effect of antidumping investigation on the likelihood of exit, trade intermediaries versus direct exporters

\begin{tabular}{l|ccc}
\hline & $\mathbf{1}$ & $\mathbf{2}$ & $\mathbf{3}$ \\
Dependent Variable & \multicolumn{3}{c}{ exit } \\
\hline Log (export volume) & $-0.033^{* *}$ & $-0.033^{* *}$ & $-0.032^{* *}$ \\
& $(0.005)$ & $(0.005)$ & $(0.005)$ \\
Trade intermediaries & & $-0.175^{* *}$ & $-0.130^{* *}$ \\
& & $(0.020)$ & $(0.024)$ \\
Final duties & & & 0.001 \\
& & & $(0.001)$ \\
Product fixed effects & yes & yes & yes \\
\hline Number of observations & 16,580 & 16,580 & 11,544 \\
Pseudo R2 & 0.027 & 0.030 & 0.028 \\
\hline
\end{tabular}

Note: Standard errors, clustered at the product level, are reported in the bracket.

** represent statistical significance at the $1 \%$ level. 
Table 4: The effect of antidumping investigation on the likelihood of exit, single-product direct exporters versus multiple-product direct exporters

\begin{tabular}{l|ccc}
\hline & $\mathbf{1}$ & $\mathbf{2}$ & $\mathbf{3}$ \\
Dependent Variable & & exit & \\
\hline Log (export volume) & $-0.050^{* *}$ & $-0.061^{* *}$ & $-0.057^{* *}$ \\
& $(0.006)$ & $(0.006)$ & $(0.005)$ \\
Single-product firms & & $1.184^{* *}$ & $1.163^{*}$ \\
& & $(0.075)$ & $(0.091)$ \\
Final duties & & & $0.003^{* *}$ \\
& & & $(0.001)$ \\
Product fixed effects & yes & yes & yes \\
\hline Number of observations & 9,035 & 9,035 & 4,246 \\
Pseudo R2 & 0.034 & 0.056 & 0.077 \\
\hline
\end{tabular}

Note: Standard errors, clustered at the product level, are reported in the bracket. * and ${ }^{* *}$ represent statistical significance at the $5 \%$ and $1 \%$ level, respectively. 
Table 5: The effect of antidumping investigation on export prices

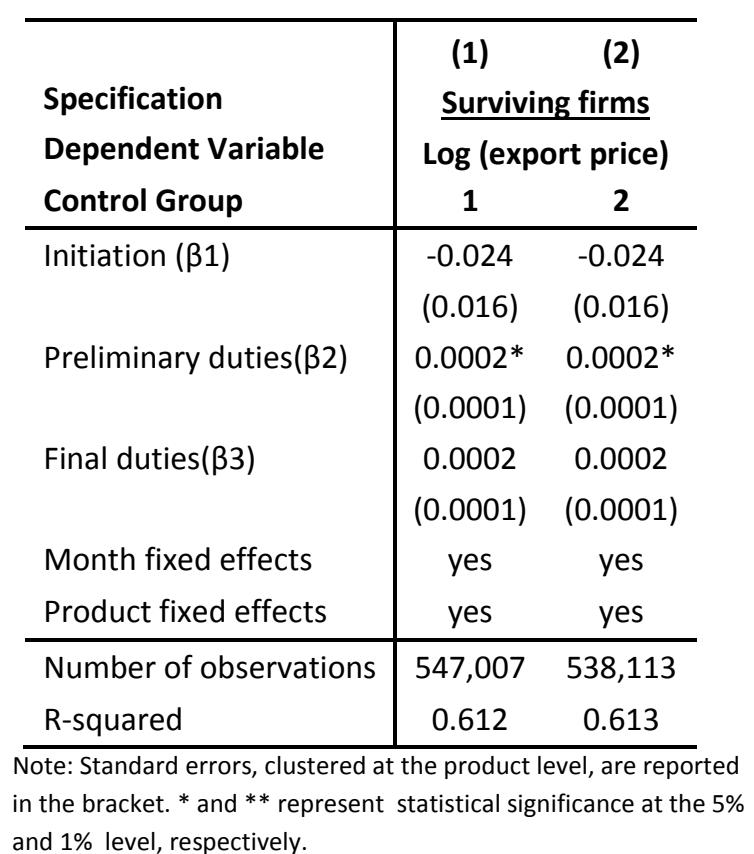


Table 6: The effect of antidumping investigation on trade deflection

\begin{tabular}{|c|c|c|}
\hline \multirow{3}{*}{$\begin{array}{l}\text { Dependent variable } \\
\text { Control group }\end{array}$} & \multirow{2}{*}{\multicolumn{2}{|c|}{$\begin{array}{cc}1 & 2 \\
\log \text { (export volume) }\end{array}$}} \\
\hline & & \\
\hline & 1 & 2 \\
\hline \multirow[t]{2}{*}{ Initiation ( $\beta 1$ ) } & -0.173 & -0.211 \\
\hline & $(0.128)$ & $(0.132)$ \\
\hline \multirow[t]{2}{*}{ Preliminary Duties( $\beta 2)$} & 0.0003 & 0.0004 \\
\hline & $(0.0007)$ & $(0.0007)$ \\
\hline \multirow[t]{2}{*}{ Final duties $(\beta 3)$} & -0.0007 & -0.0005 \\
\hline & $(0.001)$ & $(0.001)$ \\
\hline Month fixed effects & yes & yes \\
\hline Product fixed effects & yes & yes \\
\hline Number of observations & 12,484 & 11,561 \\
\hline R-squared & 0.85 & 0.857 \\
\hline
\end{tabular}

